\title{
The Effectiveness of Nonoperative Treatment for Anterior Cruciate Ligament Rupture on Patient-Reported Outcomes and Muscular Strength: A Critically Appraised Topic
}

\author{
Emily R. Hunt, Cassandra N. Parise, and Timothy A. Butterfield
}

\begin{abstract}
Clinical Scenario: Anterior cruciate ligament (ACL) ruptures are one of the most common injuries in young athletic populations. The leading treatment for these injuries is ACL reconstruction (ACL-r); however, nonoperative treatments are also utilized. Following ACL-r, patients experience prolonged muscle weakness and atrophy of the quadriceps muscle group, regardless of rehabilitation. Nonoperative treatment plans following ACL injury exist, but their outcomes are less familiar, in spite of providing insight as a nonsurgical "control" for postsurgical rehabilitation outcomes. Therefore, the purpose of this critically appraised topic was to evaluate quadriceps strength and function following nonoperative ACL rehabilitation using objective and subjective measures including isokinetic dynamometry, the single-leg hop test, and the International Knee Documentation Committee (IKDC) subjective knee form. Focused Clinical Question: What are the effects of nonoperative treatment on peak isokinetic knee-extensor torque, the single-leg hop tests, and the IKDC in patients who have sustained an ACL rupture? Summary of Key Findings: Patients who underwent nonsurgical ACL treatment produced limb symmetry index, with the side-to-side torque difference expressed as a percentage, and values at or above $90 \%$ for all 4 single-leg hop tests and strength tests similar to ACL-r patients. All studies showed individuals had higher IKDC scores at baseline collection when compared with patients who underwent ACL-r but showed lower IKDC scores at long-term followup compared with ACL-r patients. Clinical Bottom Line: Nonoperative treatments of ACL injuries yield similar long-term results in quadriceps strength as ACL-r. Due to the quality of evidence and the absence of randomized controlled trials on this topic, these outcomes should be considered with caution. Strength of Recommendation: The Oxford Centre for Evidence-Based Medicine taxonomy recommends a grade of B for level 2 evidence with consistent findings.
\end{abstract}

Keywords: ACL, muscle strength, function

\section{Clinical Scenario}

Anterior cruciate ligament (ACL) injuries are among the most common traumatic athletic injuries, affecting upwards of 200,000 individuals per year in the United States. ${ }^{1}$ For those US patients who wish to continue participation in competitive athletics, ligament reconstruction has become the preferred method of treatment. ${ }^{2}$ In the United States, the rate of ACL reconstruction (ACL-r) continues to rise annually, reaching 52 reconstructions per 100,000 of the population in 2015. ${ }^{3}$ This rate is second to Australia, which continues to lead the world with 77.4 ACL-r per 100,000 citizens, with the greatest increase in ACL-r among those aged $4-15$ years. ${ }^{4}$

The primary purpose for ACL-r is the restoration of joint congruity concomitant with increased knee stability. ${ }^{5}$ However, despite the advancements and improvements in surgical techniques, instrumentation, and postsurgical care and rehabilitation, individuals who undergo ACL-r inevitably suffer from persistent quadriceps atrophy and weakness for a long term. ${ }^{6}$ These unresolved strength deficits decrease athletic performance, increase the risk of reinjury, ${ }^{7}$ and likely contribute to the progression of cartilage damage within the joint. ${ }^{8}$ Therefore, the dogma that ACL-r is the most efficacious treatment following ACL injury should be taken with caution. In a

Hunt is with the is with the Department of Physical Therapy, College of Health Sciences; Parise and Butterfield are with the Department of Athletic Training and Clinical Nutrition, College of Health Sciences; Hunt and Butterfield are also with the Center for Muscle Biology; University of Kentucky, Lexington, KY, USA. Hunt (Emily.hunt@uky.edu) is corresponding author. 21-year population study, Schilaty et $\mathrm{al}^{9}$ found that out of almost 2000 patients, $75 \%$ of them underwent ACL-r and 98\% of those were under the age of $18 .{ }^{10}$ Although the rates of nonoperative treatment of ACL injury continue to lag behind the rate of surgical intervention in the United States, there is a growing support within the international community for conservative treatment. Therefore, the purpose of this critically appraised topic (CAT) is to review the best and most current literature that measured the effects of conservative, nonoperative ACL treatment on quadriceps strength and patient-perceived function using isokinetic dynamometry, the single-leg hop test, or the International Knee Documentation Committee (IKDC) subjective knee form.

\section{Focused Clinical Question}

What are the effects of nonoperative treatment on isokinetic muscle strength, the single-leg hop test, and the iKDC-2000 in patients who have sustained an ACL rupture?

\section{Search Strategy}

In November 2018, we performed a comprehensive computerized search using the following terms (Figure 1), using the PICO strategy. ${ }^{11}$

- Patient/Client group: ACL rupture

- Intervention: nonoperative treatment protocol

- Comparison: ligamentous reconstruction OR no

- Outcome: patient-reported outcomes AND muscular strength 


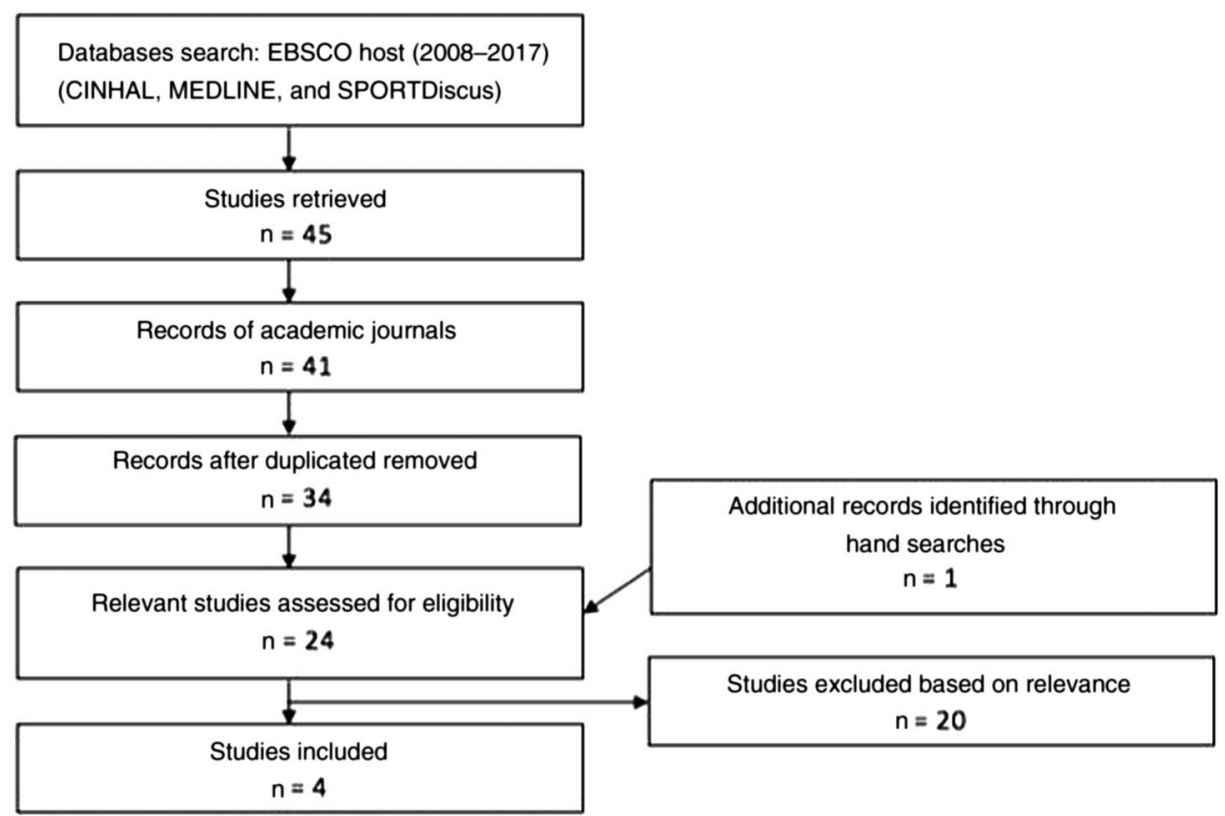

Figure 1 - Summary of search history and included studies.

\section{Sources of Evidence Searched}

- EBSCOhost

O CINAHL

O SPORTDiscus

O MEDLINE

O Additional resources obtained via review of reference list and hand search

\section{Inclusion and Exclusion Criteria}

The criteria for inclusion were as follows:

- Studies that investigated the effectiveness of nonoperative treatments

- Studies that investigated ACL ruptures

- Studies that included outcome measures of patient-reported outcomes or muscular strength

- Limited to studies published within the past 10 years (2008-2018)

- Limited to English

- Level 2 evidence or higher

The criteria for exclusion were as follows:

- Studies that investigated non ACL ruptures (ie, ACL partial thickness tear)

- Studies that investigated other subsequent pathologies because of ACL injury

- Studies that did not investigate the effects of nonoperative treatment on ACL injury

- Studies that were not in English

- Level 3 evidence or lower

- Systematic reviews and meta-analysis

\section{Evidence of Quality Assessment}

- The Strengthening of Reporting of Observational studies in Epidemiology statement was used to determine the validity of the included studies. The 2 authors (E.H. and C.P.) independently scored and reviewed each of the articles, and after review both authors (E.H. and C.P.) reached an agreement about the study quality and inclusion.

\section{Summary of Search and Key Findings}

- The literature search returned 43 studies (Figure 1) related to the clinical question. After review, 39 studies were excluded because they did not meet the inclusion criteria for this CAT. About 4 prospective cohort studies ${ }^{5,12-14}$ met the inclusion criteria, and they are described in Table 1.

- Each included study evaluated the effects of nonoperative treatment algorithms for ACL injury or compared conservative treatment and ACL-r.

- Collectively, the 4 studies (Table 1) reported significant improvements in both patient-reported outcomes and muscular strength when comparing long-term follow-up to the time of injury. In addition, in the studies that compared the effects of nonoperative treatment with ACL-r, the outcome measures were similar between the 2 groups.

\section{Results of Evidence Quality Assessment}

A total of 4 studies were identified as the best evidence and selected for inclusion in this CAT. The 4 studies were selected because they were level 2 evidence and had Strengthening of Reporting of Observational studies in Epidemiology scores of at least 17/22. About 3 studies ${ }^{5,13,14}$ examined the effects 
Table 1 Characteristics of Included Studies

\begin{tabular}{|c|c|c|c|c|}
\hline & $\begin{array}{l}\text { Study } 1 \\
\text { Moksnes et al }{ }^{12}(2008)\end{array}$ & $\begin{array}{l}\text { Study } 2 \\
\text { Moksnes et } \mathrm{al}^{5} \text { (2009) }\end{array}$ & $\begin{array}{l}\text { Study } 3 \\
\text { Moksnes et al }{ }^{11}(2013)\end{array}$ & $\begin{array}{l}\text { Study } 4 \\
\text { Grindem et al }{ }^{13}(2014)\end{array}$ \\
\hline $\begin{array}{l}\text { Study/ } \\
\text { design }\end{array}$ & Prospective cohort study & Prospective cohort study & Prospective cohort study & Prospective cohort study \\
\hline Participants & $\begin{array}{l}\text { A total of } 26 \text { patients; } 11 \text { girls } \\
\text { and } 15 \text { boys were included } \\
\text { throughout the entirety of the } \\
\text { study. } 20 \text { patients were treated } \\
\text { nonoperatively, while } 6 \text { patients } \\
\text { were treated with ACL-r. }\end{array}$ & $\begin{array}{l}\text { At baseline, } 125 \text { patients, } \\
56 \text { females and } 69 \text { males (age } \\
27.2[8.6] \text { ) were included in the } \\
\text { study. At follow-up, } 102 \text { pa- } \\
\text { tients remained; } 52 \text { patients in } \\
\text { the nonoperative group and } \\
50 \text { patients in the ACL-r group. }\end{array}$ & $\begin{array}{l}\text { A total of } 46 \text { patients; } \\
16 \text { females and } 30 \text { males } \\
\text { (age at baseline } 11.8[1.3] \text { ) were } \\
\text { included in the study. } 34 \text { pa- } \\
\text { tients remained in the nonoper- } \\
\text { ative treatment group and } \\
10 \text { patients opted to undergo } \\
\text { ACL-r. }\end{array}$ & $\begin{array}{l}\text { A total of } 143 \text { patients, } \\
80 \text { females and } 63 \text { males } \\
\text { were included in the study. } \\
43 \text { patients chose to be treated } \\
\text { nonoperatively and } 100 \text { patients } \\
\text { were treated with ACL-r. }\end{array}$ \\
\hline Inclusion & $\begin{array}{l}\text { ACL injury before the age of } 13 \text {, } \\
2 \text { y from injury to or recon- } \\
\text { struction to follow-up period, } \\
\text { ACL rupture confirmed by } \\
\text { MRI, clinical examination by } \\
\text { one experienced orthopedic } \\
\text { surgeon, and positive Lachman } \\
\text { test. }\end{array}$ & $\begin{array}{l}\text { Level } 1 \text { or level } 2 \text { activities, } \\
\text { unilateral ACL rupture. }\end{array}$ & $\begin{array}{l}\text { Traumatic complete intrasub- } \\
\text { stance ACL injury sustained at } \\
\text { the age of } 12 \text { or younger. }\end{array}$ & $\begin{array}{l}\text { ACL injury within past } 3 \text { mo, } \\
\text { MRI diagnosis, 3-mm differ- } \\
\text { ence between knees using } \\
\text { KT-1000 (Medmetric, San } \\
\text { Deigo, CA), } 13-60 \text { y old, } \\
\text { participate in level } 1 \text { or level } 2 \\
\text { activities at least } 2 \text { times a week. }\end{array}$ \\
\hline Exclusion & $\begin{array}{l}\text { ACL avulsion injury, posterior } \\
\text { cruciate ligament injury, or } \\
\text { intraarticular fractures. }\end{array}$ & $\begin{array}{l}\text { Posterior cruciate ligament } \\
\text { injury, intraarticular fractures, } \\
\text { symptomatic meniscal injury, } \\
\text { cartilage injury affecting the } \\
\text { subchondral bone plate, or any } \\
\text { other injury to the leg. }\end{array}$ & $\begin{array}{l}\text { Tibial or femoral ACL avulsion } \\
\text { fractures. }\end{array}$ & $\begin{array}{l}\text { Current or pervious injury to } \\
\text { contralateral leg if MRI showed } \\
\text { another grade } 3 \text { ligament injury, } \\
\text { fracture or full-thickness artic- } \\
\text { ular cartilage damage, or pa- } \\
\text { tients with symptomatic } \\
\text { meniscal injury. }\end{array}$ \\
\hline $\begin{array}{l}\text { Follow-up } \\
\text { periods }\end{array}$ & $\begin{array}{l}\text { Follow-up: taken at a minimum } \\
\text { of } 2 \text { y post ACL injury. }\end{array}$ & $\begin{array}{l}\text { Baseline: taken after } 3 \text { mo of } \\
\text { rehabilitation program. Baseline } \\
\text { testing within first } 6 \text { mo post } \\
\text { index injury. } \\
\text { 1-y follow-up: } 1 \text { y after baseline } \\
\text { measurement or } 1 \text { y after ACL-r. }\end{array}$ & $\begin{array}{l}\text { Baseline: taken after patient } \\
\text { completed phase } 2 \text { of the reha- } \\
\text { bilitation program previously } \\
\text { published by the investigators } \\
\text { and could perform single-legged } \\
\text { hops without pain. Mean time } \\
\text { from injury to baseline testing } \\
\text { was } 11.7 \text { (11.5) mo. } \\
1 \text {-y follow-up: } 1 \text { y post baseline. } \\
2 \text {-y follow-up: } 2 \text { y post baseline. }\end{array}$ & $\begin{array}{l}\text { Baseline: taken at a mean of } \\
\text { 2-mo postinjury. Before base- } \\
\text { line, completed rehabilitation to } \\
\text { resolve any initial impairments } \\
\text { from the injury. } \\
6 \text {-wk test: taken after participa- } \\
\text { tion in the } 5 \text {-wk rehabilitation } \\
\text { protocol described by Eitzen } \\
\text { et al. }{ }^{15} \\
2 \text {-y follow-up: taken } 2 \text { y after 6- } \\
\text { wk test or } 2 \text { y after ACL-r. }\end{array}$ \\
\hline $\begin{array}{l}\text { Outcome } \\
\text { measure(s) }\end{array}$ & $\begin{array}{l}\text { Single-leg hop tests (single hop, } \\
\text { triple hop, triple crossover hop, } \\
6 \text {-m timed hop), IKDC-2000, } \\
\text { and isokinetic muscle strength } \\
\text { of knee. }\end{array}$ & $\begin{array}{l}\text { Single-leg hop tests (single hop, } \\
\text { triple hop, triple crossover hop, } \\
\text { and 6-m timed hop) and IKDC- } \\
2000 \text {. }\end{array}$ & $\begin{array}{l}\text { IKDC-2000 (with the help of a } \\
\text { parent), isokinetic muscle } \\
\text { strength of the knee, and the } 4 \\
\text { single-leg hop tests. }\end{array}$ & $\begin{array}{l}\text { Isokinetic muscle strength of the } \\
\text { knee and IKDC-2000. }\end{array}$ \\
\hline $\begin{array}{l}\text { Main } \\
\text { Findings }\end{array}$ & $\begin{array}{l}\text { IKDC mean score of } 85 \text { ( } 71- \\
\text { 95). All single-leg hop tests } \\
\text { above } 90 \% \text { LSI. Both quadri- } \\
\text { ceps and hamstring strength } \\
\text { were above } 90 \% \text { LSI. }\end{array}$ & $\begin{array}{l}\text { At baseline: subjects who were } \\
\text { older, performed better on the } \\
\text { triple crossover and 6-m time } \\
\text { hop, and had better IKDC- } 2000 \\
\text { scores opted to go through with } \\
\text { nonoperative treatment. } \\
\text { 1-y follow-up: nonoperative } \\
\text { group performed significantly } \\
\text { better on the single and triple } \\
\text { hop tests. ACL-r group had } \\
\text { significantly higher IKDC- } \\
2000 \text {. }\end{array}$ & $\begin{array}{l}\text { About } 77 \% \text { of children re- } \\
\text { mained ACL deficient through- } \\
\text { out } 2 \text { y. } 91 \% \text { of ACL deficient } \\
\text { children continued to participate } \\
\text { in pivoting sports. IKDC-2000 } \\
\text { had a mean score of } 82.7 \text { at } \\
\text { baseline and increased to an } \\
82.9 \text { at } 2 \text {-y follow-up. Did not } \\
\text { show a significant increase in } \\
\text { value over the course of the } \\
\text { study. All single-leg hop tests } \\
\text { above } 90 \% \text { LSI at baseline. } \\
\text { There was a significant change } \\
\text { in single and 6-m timed. At } \\
\text { baseline, both quadriceps and } \\
\text { hamstring LSI strength mea- } \\
\text { surements were above } 90 \% \text {. No } \\
\text { significant change in either over } \\
2 \mathrm{y} \text {. }\end{array}$ & $\begin{array}{l}\text { Isokinetic muscle strength of } \\
\text { both the hamstring and quadri- } \\
\text { ceps muscle groups were at or } \\
\text { above an LSI value of } 90 \% \text {. } \\
\text { There was no significant group } \\
\text { by time change throughout the } \\
\text { course of the study. IKDC } \\
\text { scores increased throughout the } \\
\text { 2-y study; again however, there } \\
\text { was not a significant group by } \\
\text { time relationship. }\end{array}$ \\
\hline
\end{tabular}


Table 1 (continued)

\begin{tabular}{|c|c|c|c|c|}
\hline & $\begin{array}{l}\text { Study } 1 \\
\text { Moksnes et al }{ }^{12}(2008)\end{array}$ & $\begin{array}{l}\text { Study } 2 \\
\text { Moksnes et } a^{5}(2009)\end{array}$ & $\begin{array}{l}\text { Study } 3 \\
\text { Moksnes et al }{ }^{11} \text { (2013) }\end{array}$ & $\begin{array}{l}\text { Study } 4 \\
\text { Grindem et al }{ }^{13}(2014)\end{array}$ \\
\hline $\begin{array}{l}\text { Level of } \\
\text { evidence }\end{array}$ & $\begin{array}{l}2 \mathrm{~b} \text { according to the Oxford } \\
\text { Centre for Evidence-Based } \\
\text { Medicine taxonomy. }\end{array}$ & $\begin{array}{l}2 \mathrm{~b} \text { according to the Oxford } \\
\text { Centre for Evidence-Based } \\
\text { Medicine taxonomy. }\end{array}$ & $\begin{array}{l}2 \mathrm{~b} \text { according to the Oxford } \\
\text { Centre for Evidence-Based } \\
\text { Medicine taxonomy. }\end{array}$ & $\begin{array}{l}2 \mathrm{~b} \text { according to the Oxford } \\
\text { Centre for Evidence-Based } \\
\text { Medicine taxonomy. }\end{array}$ \\
\hline $\begin{array}{l}\text { Validity } \\
\text { Score }\end{array}$ & $18 / 22$ & $17 / 22$ & $17 / 22$ & $21 / 22$ \\
\hline Conclusion & $\begin{array}{l}\text { At } 2 \text { y after ACL injury, ACL } \\
\text { deficient patients had adequate } \\
\text { knee function. }\end{array}$ & $\begin{array}{l}\text { A majority of the individuals } \\
\text { who were treated with a con- } \\
\text { servative treatment algorithm } \\
\text { were able to return to preinjury } \\
\text { activity level. In addition, when } \\
\text { compared with individuals who } \\
\text { underwent ACL-r, nonoperative } \\
\text { subjects had similar perfor- } \\
\text { mance-based outcome } \\
\text { measures. }\end{array}$ & $\begin{array}{l}\text { Majority of children remained } \\
\text { ACL deficient and had adequate } \\
\text { knee function. }\end{array}$ & $\begin{array}{l}\text { At } 2-y \text { postinjury, the nonsur- } \\
\text { gically treated group had LSI } \\
\text { values }>90 \text { for both knee } \\
\text { extension and flexion. The } \\
\text { IKDC- } 2000 \text { scores improved } \\
\text { over } 2 \mathrm{y} \text {. }\end{array}$ \\
\hline
\end{tabular}

Abbreviations: ACL, anterior cruciate ligament; ACL-r, ACL-reconstruction; IKDC, International Knee Documentation Committee; LSI, limb symmetry index; MRI magnetic resonance imagining.

of nonoperative treatment on isokinetic strength of the quadriceps and hamstrings. In addition, the studies conducted by Moksnes et $\mathrm{al}^{5,12,13}$ examined the effects of nonoperative treatment on strength using the single-leg hop test and Moksnes et $\mathrm{al}^{5}$ was the only study to compare the nonoperative ACL group directly to the ACL-r group. All 4 studies examined the effects of nonoperative ACL treatment on the IKDC-2000. ${ }^{5,12-14}$ Moksnes et al ${ }^{13}$ received a validity score of $18 / 22$ for the failure to include the study design in the abstract, address potential sources of bias, and discuss the external validity of the study. Moksnes et al ${ }^{11}$ did not discuss potential confounders of each variable or the external validity of the study.

\section{Clinical Bottom Line}

There is strong evidence to support that conservative treatment of ACL injuries obtains similar outcomes as ACL ligamentous reconstruction at long-term follow-up periods. All studies included in this critically appraised topic, ${ }^{5,12-14}$ generated similar results: at follow-up patients who underwent nonsurgical treatment of ACL injury produced limb symmetry index (LSI) values at or above $90 \%$ for all 4 single-leg hop tests, as well as, knee-extensor and -flexor isokinetic muscular strength. In addition, all studies showed individuals had higher IKDC-2000 scores (higher scores indicate better knee function) at baseline collection when compared with patients who underwent ACL-r but showed lower IKDC-2000 scores at long-term follow-up compared with ACL-r patients. There is grade B evidence that nonoperative treatment yields satisfactory results in the long term. The Oxford Centre for Evidence-Based Medicine taxonomy recommends a grade of $\mathrm{B}$ for level 2 evidence with consistent findings. ${ }^{16}$

\section{Implications for Practice, Education, and Future Research}

The prevalence of ACL injuries in athletes is increasingly escalating. While ACL-r is the current favored treatment, it is important that all treatment options are carefully examined in order to provide patients with the most efficient and effective care. Therefore, this CAT was completed to evaluate the best literature regarding the use of nonoperative treatment regimens for ACL injuries. A total of 4 cohort studies were included in the investigation. From these 4 studies, the main findings were concluded that nonsurgical treatment of ACL injuries could yield satisfactory results when the outcome measures include the IKDC-2000 at baseline, single-leg hop test, and isokinetic muscle strength.

The IKDC is a knee-specific, patient-reported assessment tool used to evaluate symptoms, function during daily activities, and levels of symptom-free sports activity. ${ }^{17}$ It has been determined to be a reliable and valid instrument for the outcome measures mentioned above and was therefore seen as an appropriate tool to be used in this critically appraised topic. ${ }^{18,19}$ However, it should be noted that in a study conducted by Kessler et al, ${ }^{20}$ the IKDC scores were determined based upon tibiofemoral anterior-posterior translation. Because patients who undergo ligamentous reconstruction have inevitable restoration of ligamentous stability, the comparison of anterior-posterior translation between nonoperative groups and ACL-r groups is not informative. Due to the use of this criteria as a scoring variable, future studies should take caution when using the IKDC as a tool of comparison between conservatively treated and ACL-r groups. It is important to note that while patient-reported outcomes are reliable and valid tools, they are subjective to normal patient function and how the patient feels during a given time frame. Several studies ${ }^{5,14}$ showed that patients who opted to go through nonoperative treatment presented with better IKDC-2000 scores at baseline. However, the patient population of these nonoperative groups was significantly older than the patients who decided to go through with ACL-r and had an altogether lower activity level. This suggests that activities of daily living and preinjury activity level are important factors when it comes to deciding between ACL-r and conservative treatment options.

Unfortunately, persistent quadriceps weakness has become a comorbidity to ACL-r and has spurred many novel treatments, rehabilitation programs, and medical technologies in attempts to address this issue. However, strength deficits of $20 \%$ lasting for 
over 2 years have still been documented following ACL-r. ${ }^{1,21,22}$ In 3 of the 4 studies included in this critically appraised topic, isovelocity torque output was used as a measure of quadriceps and hamstring strength in subjects treated conservatively following ACL injury. ${ }^{12-14}$ All 3 studies used the following standard procedure: 10-minute warm-up on a stationary bike followed by 4 practice trials performed with submaximal effort at $60 \%$ s. Finally, 5 -test repetitions were performed with maximal effort at the same angular velocity of $60 \%$, starting with the uninvolved limb. Strength deficits between extremities were reported as an LSI, or simply the side-to-side torque difference expressed as a percentage (peak torque of involved limb)/(peak torque of uninvolved limb) $\times 100$. Although LSI values $<90 \%$ are considered abnormal, ${ }^{23}$ Moksnes et al ${ }^{12,13}$ reported quadriceps and hamstring LSI values at or above $90 \%$ at baseline and follow-up. Moreover, Grindem et $\mathrm{al}^{14}$ further reported that only 9 out of 43 nonsurgically treated patients exhibited quadriceps and hamstring LSI values of $<90 \%$ at follow-up. These findings demonstrate that nonoperative treatments of ACL injuries have the possibility to produce desirable muscle strength.

The single-leg hop tests have been shown to be reliable and valid tests used to measure neuromuscular control, strength, and confidence in the limb. ${ }^{24-26}$ The test only requires a standard tape measure making it accessible to clinicians in a variety of settings, and deficits between extremities can easily be reported as LSI values. Moksnes et $\mathrm{al}^{12}$ reported LSI values at or above 90\% for all single-leg hop tests at baseline and at all follow-up periods ( 1 and $2 \mathrm{y}$ ). Additionally, Moksnes et $\mathrm{al}^{5}$ and Grindem et a ${ }^{14}$ reported LSI values above $90 \%$ for all single-leg hop tests at follow-up, demonstrating that nonsurgical treatments of ACL ruptures can improve neuromuscular control, strength, and confidence as measured by the single-leg hop test.

Interestingly, all of the studies included in this CAT report baseline LSI values at or above $90 \%$. This could be due to baseline outcomes being measured at least 6 months after injury. Outcome measures examined by Moksnes et $\mathrm{al}^{13}$ did not get evaluated until at least 2 years after ACL injury. Additionally, it was routine for patients that were included in these studies to undergo preoperative rehabilitation sessions to resolve initial impairments of ACL injury. Recently, it was shown that patients who underwent ACL-r were typically returned to contact sports within 6 months post surgery. ${ }^{10,23}$ Grindem et al ${ }^{14}$ reported that athletes who were treated nonoperatively returned primarily to nonpivoting sports. Although, whether functional and strength differences exist between conservative and surgical treatment at the time when most highly active individuals are returned to sport is unknown and should be the focus of future studies.

The findings of this CAT imply that nonoperative treatments of ACL injuries are adequate options in restoration of patient function, as well as patient strength at long-term follow-ups. However, patient goals, normal activities of daily living, and sport activity level should all be taken into consideration when choosing the best treatment plan for patients. Furthermore, the absence of randomized control trials on this topic hinders the strength of these recommendations. Although further investigation regarding this topic is warranted, patients should be thoroughly informed of all treatment options available. Evidence suggests that conservative treatment has the ability to generate positive outcomes in the long term and should be considered for ACL-deficient individuals.

\section{References}

1. Palmieri-Smith RM, Thomas AC, Wojtys EM. Maximizing quadriceps strength after ACL reconstruction. Clin Sports Med. 2008;27(3):405-424. PubMed ID: 18503875 doi:10.1016/j.csm. 2008.02.001

2. Beynnon BD, Johnson RJ, Abate JA. Treatment of anterior cruciate ligament injuries: part 1. Am J Sports Med. 2005;33(10):1579-1602. PubMed ID: 16199611 doi:10.1177/0363546505279913

3. Moses B, Orchard J, Orchard J. Systematic review: annual incidence of ACL injury and surgery in various populations. Res Sports Med. 2012;20(3-4):157-179. doi:10.1080/15438627.2012.680633

4. Zbrojkiewicz D, Vertullo C, Grayson JE. Increasing rates of anterior cruciate ligament reconstruction in young Australians, 2000-2015. Med J Aust. 2018;208(8):354-358. PubMed ID: 29669497 doi:10. 5694/mja17.00974

5. Moksnes H, Risberg MA. Performance-based functional evaluation of non-operative and operative treatment after anterior cruciate ligament injury. Scand J Med Sci Sports. 2009;19(3):345-355. PubMed ID: 18510592 doi:10.1111/j.1600-0838.2008.00816.x

6. Mendias CL, Lynch EB, Davis ME, et al. Changes in circulating biomarkers of muscle atrophy, inflammation, and cartilage turnover in patients undergoing anterior cruciate ligament reconstruction and rehabilitation. Am J Sports Med. 2013;41(8):1819-1826. PubMed ID: 23739685 doi:10.1177/0363546513490651

7. Ingersoll CD, Grindstaff TL, Pietrosimone BG, Hart JM. Neuromuscular consequences of anterior cruciate ligament injury. Clin Sports Med. 2008;27(3):383-404. PubMed ID: 18503874 doi:10.1016/j. csm.2008.03.004

8. Herzog W, Longino D, Clark A. The role of muscles in joint adaptation and degeneration. Langenbecks Arch Surg. 2003;388(5): 305-315. PubMed ID: 14504930 doi:10.1007/s00423-003-0402-6

9. Schilaty ND, Nagelli C, Bates NA, Sanders TL, Krych AJ, Stuart MJ, Hewett TE. Incidence of second anterior cruciate ligament tears and identification of associated risk factors from 2001 to 2010 using a geographic database. Orthopaedic J Sports Med. 2017;5(8):232596 7117724196.

10. Petersen W, Zantop T. Return to play following ACL reconstruction: survey among experienced arthroscopic surgeons (AGA instructors). Arch Orthop Trauma Surg. 2013;133(7):969-977. PubMed ID: 23604790 doi:10.1007/s00402-013-1746-1

11. Huang X, Lin J, Demner-Fushman D. Evaluation of PICO as a knowledge representation for clinical questions. AMIA Аnnu Symp Proc. 2006:359-363.

12. Moksnes H, Engebretsen L, Eitzen I, Risberg MA. Functional outcomes following a non-operative treatment algorithm for anterior cruciate ligament injuries in skeletally immature children 12 years and younger. A prospective cohort with 2 years follow-up. Br J Sports Med. 2013;47(8):488-494. PubMed ID: 23446640 doi:10.1136/ bjsports-2012-092066

13. Moksnes H, Engebretsen L, Risberg M. Performance-based functional outcome for children 12 years or younger following anterior cruciate ligament injury: a two to nine-year follow-up study. Knee Surg Sports Traumatol Arthrosc. 2008;16(3):214-223. PubMed ID: 18157486 doi:10.1007/s00167-007-0469-7

14. Grindem H, Eitzen I, Engebretsen L, Snyder-Mackler L, Risberg MA. Nonsurgical or surgical treatment of ACL injuries: knee function, sports participation, and knee reinjury: the Delaware-Oslo ACL cohort study. J Bone Joint Surg Am. 2014;96(15):1233-1241. PubMed ID: 25100769 doi:10.2106/JBJS.M.01054 
15. Eitzen I, Holm I, Risberg MA. Preoperative quadriceps strength is a significant predictor of knee function two years after anterior cruciate ligament reconstruction. Br J Sports Med. 2009;43:371-376.

16. OCEBM Levels of Evidence Working Group. The Oxford 2011 Levels of Evidence. Oxford Centre for Evidence-Based Medicine. 2011. http://www.cebm.net/index.aspx?o=5653

17. Greco NJ, Anderson AF, Mann BJ, et al. Responsiveness of the international knee documentation committee subjective knee form in comparison to the Western Ontario and McMaster Universities Osteoarthritis Index, modified Cincinnati Knee rating system, and Short Form 36 in patients with focal articular cartilage defects. Am J Sports Med. 2010;38(5):891-902. PubMed ID: 20044494 doi:10. $1177 / 0363546509354163$

18. Irrgang JJ, Anderson AF, Boland AL, et al. Development and validation of the international knee documentation committee subjective knee form. Am J Sports Med. 2001;29(5):600-613. PubMed ID: 11573919 doi:10.1177/03635465010290051301

19. Irrgang JJ, Anderson AF, Boland AL, et al. Responsiveness of the international knee documentation committee subjective knee form. Am J Sports Med. 2006;34(10):1567-1573. PubMed ID: 16870824 doi: $10.1177 / 0363546506288855$

20. Kessler MA, Behrend H, Henz S, Stutz G, Rukavina A, Kuster MS. Function, osteoarthritis and activity after ACL-rupture: 11 years follow-up results of conservative versus reconstructive treatment. Knee Surg Sports Traumatol Arthrosc. 2008;16(5):442-448. PubMed ID: 18292988 doi:10.1007/s00167-008-0498-x
21. De Jong S, Van Caspel D, Van Haeff M, Saris D. Functional assessment and muscle strength before and after reconstruction of chronic anterior cruciate ligament lesions. Arthoscopy. 2007;23:2128. doi:10.1016/j.arthro.2006.08.024

22. Keays S, Bullock-Saxton J, Newcombe P, Keays A. The relationship between knee strength and functional stability before and after anterior cruciate ligament reconstruction. $J$ Orthop Res. 2003;21:231-237. PubMed ID: 12568953 doi:10.1016/S0736-0266 (02)00160-2

23. Kvist J. Rehabilitation following anterior cruciate ligament injury: current recommendations for sports participation. Sports Med. 2004;34(4):269-280. doi:10.2165/00007256-20043404000006

24. Bolgla LA, Keskula DR. Reliability of lower extremity functional performance tests. J Orthop Sports Phys Ther. 1997;26(3):138-142. PubMed ID: 9276854 doi:10.2519/jospt.1997.26.3.138

25. Reid A, Birmingham TB, Stratford PW, Alcock GK, Giffin JR. Hop testing provides a reliable and valid outcome measure during rehabilitation after anterior cruciate ligament reconstruction. Phys Ther. 2007;87(3):337-349. PubMed ID: 17311886 doi:10.2522/ptj. 20060143

26. Petschnig R, Baron R, Albrecht M. The relationship between isokinetic quadriceps strength test and hop tests for distance and onelegged vertical jump test following anterior cruciate ligament reconstruction. J Orthop Sports Phys Ther. 1998;28(1):23-31. PubMed ID: 9653687 doi:10.2519/jospt.1998.28.1.23 